\title{
NEED ANALYSIS FOR INFUSING ENTREPRENEURSHIP SKILLS INTO RADIO, TELEVISION AND ELECTRONIC WORK PROGRAMME IN TECHNICAL COLLEGES IN NORTH-WESTERN NIGERIA
}

\section{Halliru Shuaibu*}

Departement of Technical and Engineering Education, School of Education, Faculty of Social Sciences and Humanities

Universiti Teknologi Malaysia

Malaysia

\section{Yusri Bin Kamin}

Departement of Technical and Engineering Education, School of Education, Faculty of Social Sciences and Humanities

Universiti Teknologi Malaysia

Malaysia

*Corrosponding author's Email: shalliru1976@graduate.utm.my

Author's Biography

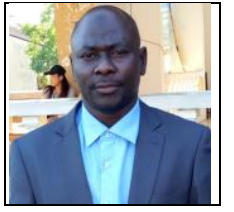

Halliru Shuaibu is a native of Kano State, Nigeria. He obtained Bachelor's and Master's degree in Industrial Technology Education (Electronics) from Federal University of Technology Minna and Modibbo Adama University of Technology, Yola. Presently, he is a PhD student in School of Education, Universiti Teknologi Malaysia (UTM), Malaysia. He is a registered teacher and worked in technical colleges in Nigeria both at ordinary and advance levels since 2001. He also served as Chief-Examiner (GSM Subject) for National Examinations Council (NECO), Nigeria, between 2014 and 2018. He has research interest in technical, vocational, collaborative, and entrepreneurship education.

Peer-review under responsibility of $3^{\text {rd }}$ Asia International Multidisciplanry Conference 2019 editorial board

(http://www.utm.my/asia/our-team/)

(C) 2019 Published by Readers Insight Publisher,

lat 306 Savoy Residencia, Block 3 F11/1,44000 Islamabad. Pakistan,

info@ readersinsight.net

This is an open access article under the CC BY-NC-ND license (http://creativecommons.org/licenses/by-nc-nd/4.0/). 


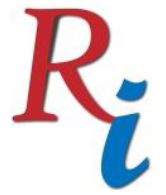

\section{Asia Proceedings of Social Sciences \\ (APSS) \\ www.readersinsight.net/APSS}

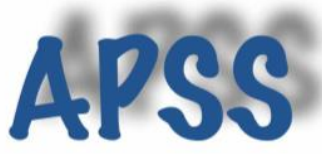

\section{Rese a r ch H i g h I igh t s}

A preliminary qualitative study is conducted as a preamble to establish the need for integrating entrepreneurship skills into Radio, Television and Electronic Work trade curriculum in technical colleges in North-West Nigeria. The study proposed one research question and result revealed that there is need for embedding entrepreneurship skills into Radio, Television and Electronic Work (RTEW) programme in technical colleges due to advancement in technology and industrial revolution across the world. For instance, online businesses and integrated curriculum merging relevant disciplines. The motivation for conducting this research is that since the year 2007 no effort was made to comprehensively review Radio, Television and Electronic Work programme by the National Board for Technical Education (NBTE) in order for graduates to properly fit into the world of work.

\section{G r a p h i c a I A b s t r a c t}

Fig. .1 Below reflects the result of the qualitative study in percentage.

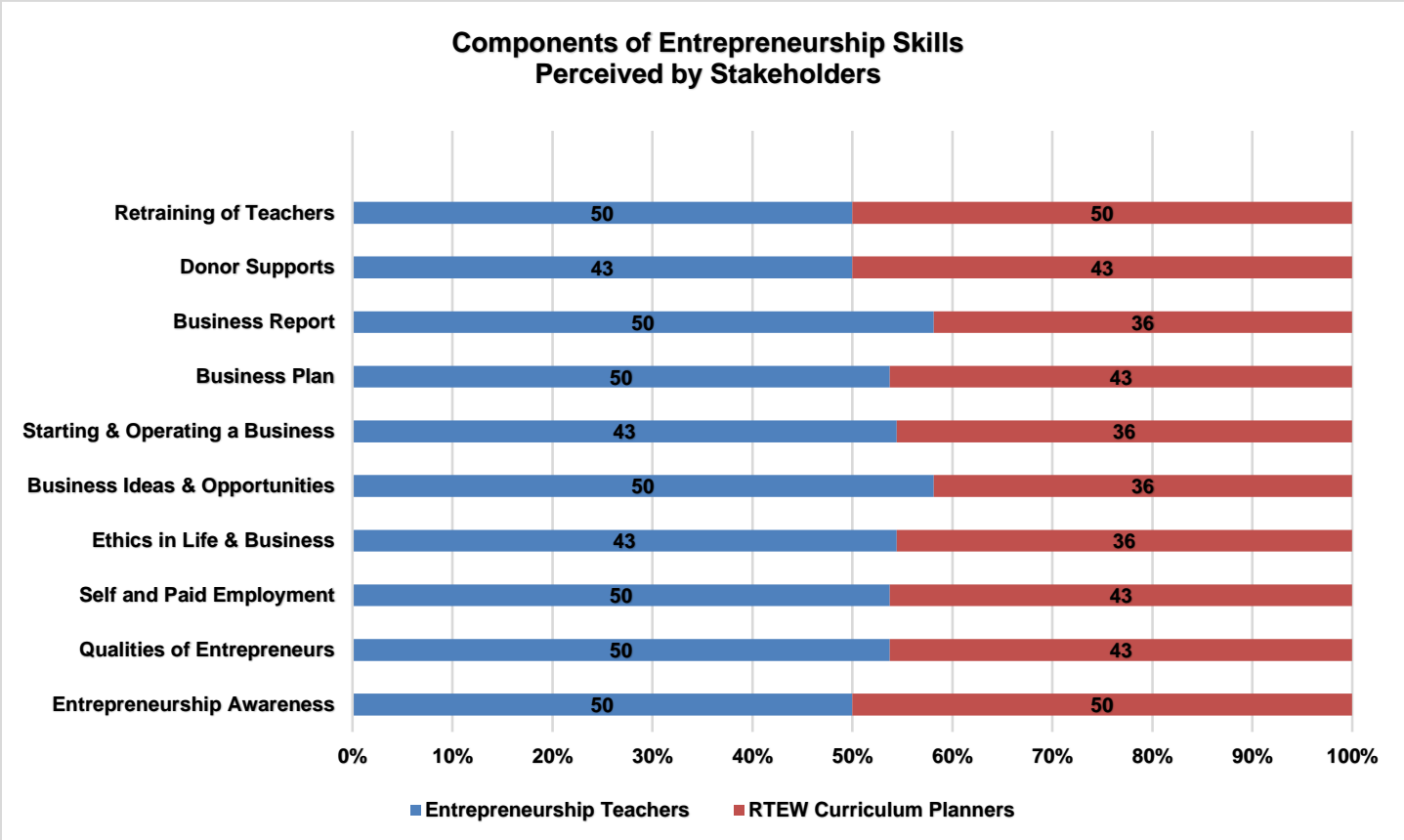

Fig. 1: Components of Entrepreneurship Skills Perceived by Stakeholders.

\section{Research Objectives}

The major aim of the study is to determine perspective of stakeholders (curriculum planners for Radio, Television and Electronic Work programme and entrepreneurship teachers from National Business Studies (NBS stream) on the need to incorporate entrepreneurship skills with Radio, Television and Electronic Work (RTEW) trade curriculum in North-Western States of Nigeria.

\section{Significance of the Study}

The findings of this study is beneficial to teachers, students, employers of labour, and curriculum development bodies such as National Board for Technical Education in Nigeria. 


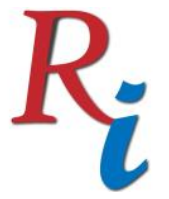

\section{Asia Proceedings of Social Sciences \\ (APSS) \\ www.readersinsight.net/APSS}

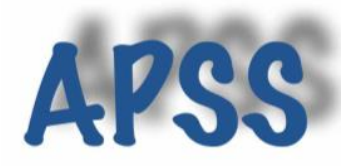

i. Teachers: Trade teachers will enhance their knowledge if RTEW technical skills and entrepreneurship skills are embedded in the curriculum of technical colleges. Trade teachers will also be better informed through retraining by using effective strategies for teaching and learning the contents of the integrated curriculum.

ii. Students: Students and graduates will become more effective as entrepreneurs by acquiring entrepreneurial skills and RTEW technical skills from one curriculum.

iii.Employers of labour will value the entrepreneurship skills to be acquired by students at technical college for promoting a specialist work force because the knowledge of the level of entrepreneurship skills acquired by students will make them efficient and competitive in business.

iv. Curriculum development bodies such as National Board for Technical Education will use the findings of the study in planning future reviews by considering the identified entrepreneurship skills to be embedded in RTEW curriculum and other curricula so that students will become well-groomed for entry into the world of work.

\section{Methodology}

\section{Research Design}

Intrinsic research design is adopted as the design for the present study. Durepos \& Wiebe (2010) stated that intrinsic research design is utilized to study an occupation, department, organization, specific groups or individuals where exploration of the case is drove by the desire and interest to know more about the uniqueness of the case under study.

\section{Sample and Sampling Technique}

7 RTEW trade curriculum planners and 7 entrepreneurship teachers were purposely selected as the sample of the study, making a total of fourteen (14). The saturation point for data collected was reached at 14th interview. Using 14 participants is supported by (Creswell, 2013) who advocated that sample size ranging from five to twenty-five can be used for a phenomenological study.

\section{Instrumentation}

Semi-structured interview and document analysis were used as the tool for data collection in the study. 3 specialists validated the interview protocol for face and content validity. The validates included 1 entrepreneurship teacher, 1 curriculum planner and 1 electronic business owner. Member checking and peer debriefing were used to establish the reliability of the interview protocol. The data received from the participants were transcribed verbatim, coded, thematically categorized and analyzed by using Nvivo 12 .

Document analysis on components of entrepreneurship skills required for integration into Radio, Television and Electronic Work curriculum was also performed. Two policy documents were analysed. They are: National Policy on Education (NPE, 2014) (Federal Republic of Nigera, 2014) and National Economic Empowerment and Development Strategy (NEEDS, 2004) (World Bank, 2005).

\section{Scope of the Study}

This study is delimited to determine the perceptions of stakeholders (entrepreneurship teachers and trade curriculum planners) for infusing entrepreneurship skills into RTEW trade curriculum. Two technical colleges in North-Western Nigeria have been used. 


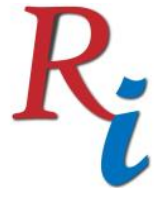

\section{Asia Proceedings of Social Sciences \\ (APSS) \\ www.readersinsight.net/APSS}

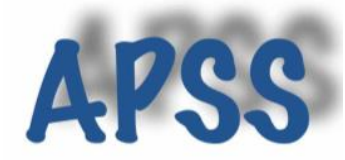

\section{Results}

Based on national policy contexts and perceptions of stakeholders on infusing entrepreneurship skills in technical colleges curricula, the following standpoints were discovered as results of the study:

i. The two policy documents (NPE and NEEDS) analyzed in this study

championed that empowerment of nigerian youths should be done through educational processes so as to generate employment and create wealth which in turn will yield socioeconomic development and eliminate poverty. The NPE exclusively mentioned entrepreneurship skills as part of the educational processes while the NEEDS does not. The NPE stated that the curriculum for technical colleges shall involve on-the-job training and commercial activities. The policy mentioned workshops as training places for on-the-job training but was silent about the places for commercial activities (NPE, p. 25).

ii. Perceptions of stakeholders from the semi-structured interview was transcribed, coded, and analyzed. The results revealed the following components of entreprenership skills as themes: entrepreneurship awareness, qualities of entrepreneurs, business ideas and opportunity, self and paid employment, starting and operating a business, ethics in life and business, business plan and business report. The themes obtained from this study are in harmony with the results obtained by researchers like (Harris, 2006) (Obiama, 2014) Kalimasi \& Herman (2016) (Nwosu, 2017). Donor support and re-training of teachers were also themes identified as complimentary factors to implement an integrated curriculum.

\section{Findings}

i. $100 \%$ of participants stated that entrepreneurship awareness can be regarded as a component of entrepreneurship skills.

ii. $93 \%$ of participants stated that qualities of entrepreneurs can be regarded a component of entrepreneurship skills.

iii.93\% of participants declared that self and paid employment can be considered as a component of entrepreneurship skills.

iv. $79 \%$ of participants declared that ethics in life and business can be viewed as a component of entrepreneurship skills.

v. $86 \%$ of participants proclaimed that business ideas and opportunities can be considered as a component of entrepreneurship skills.

vi. $79 \%$ of participants announced that starting and operating a business can be viewed as a component of entrepreneurship skills.

vii. $93 \%$ of participants announced that business plan can be regarded as a component of entrepreneurship skills.

viii. Whilst, $86 \%$ of parcipants asserted that business report can be viwed as a component of entrepreneurship skills.

ix. Finally, donor supports (86\%) and retraining needs of teachers $(93 \%)$ were perceived as complimentary factors in implementation of integrated curriculum.

In conclusion, the researchers can safely state that there is need for infusing entrepreneurship skills into RTEW trade in order to bridge the gap between policy and practice surrounding technical education in Nigeria. This is because policies analyzed indicated the need for using educational processes by colleges for socio-economic development in Nigeria. In addition, perception of stakeholders from this study buttressed the need for embedding entrepreneurship skills into the RTEW trade curriculum in technical colleges. A good avenue for producing 


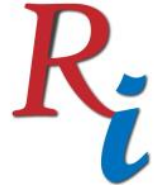

\section{Asia Proceedings of Social Sciences \\ (APSS) \\ www.readersinsight.net/APSS}

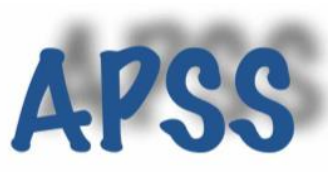

RTEW trade entrepreneurs is through learning entrepreneurship skills along with technical skills by technical college students from integrated curriculum.

\section{Acknowledgement}

The researchers are thankful to the participants of this study for conducting member check and peer debriefing on the research instrument (semi-structured interview protocol) and granting permission to record the interviews. We are also thankful to subject-matter specialists who validated the research instrument.

\section{References}

Creswell, J. W. (2013). Research design: Qualitative, quantitative and mixed methods approaches, 4th ed. Los Angeles: Sage.

Durepos, G., \& Wiebe, E. (2010). Intrinsic Case Study. SAGE. Thousand Oaks.

Federal Republic of Nigera. (2014). National Policy on Education. NERDC: Lagos-Nigeria.

Harris, T. (2006). Start-Up: A Practical Guide to Starting and Running a New Business. Berlin Heidelberg: New York: Springer.

Kalimasi, P. J., \& Herman, C. (2016). Integrating entrepreneurship education across university-wide curricula: The case of two public universities in Tanzania, 1999. https://doi.org/10.1177/0950422216666668

Nwosu, J. C. (2017). Entrepreneurship education and the challenges of graduate employability in Nigeria. Basic Research Journal of Business Management and Accounts (Vol. 6).

Obiama, G. (2014). Transferable skills in Nigerian senior secondary education curriculum. Beacon: Washington DC.: International Initiative for Impact Evaluation.

World Bank (2005). National Economic Empowerment and Development Strategy. Nigeria: IDA \& IMF: The World Bank. 